\title{
EFFECTS OF INORGANIC IODIDE ON THE INTERMEDIARY CARBOHYDRATE METABOLISM OF SURVIVING SHEEP THYROID SLICES *
}

\author{
By WILLIAM L. GREEN † AND SIDNEY H. INGBAR $\ddagger$ \\ (From the Thorndike Memorial Laboratory and Second and Fourth [Harvard] Medical \\ Services, Boston City Hospital, and the Department of Medicine, Harvard \\ Medical School, Boston, Mass.; and the Department of Medicine, \\ Seton Hall College of Medicine, Jersey City, N. J.)
}

(Submitted for publication April 2, 1963 ; accepted July 31, 1963)

The rate of hormone formation by the thyroid in vivo is greatly influenced by acute alterations in the concentration of inorganic iodide in the extracellular fluid. In the rat (1-3) and in man $(4,5)$, increasing concentrations of iodide in the plasma are associated with increased thyroidal uptake of iodine until a critical concentration of iodide is reached. Beyond this range, the formation of hormone declines. A similar relationship between extracellular iodide concentration and organic iodinations occurs in vitro in slices of sheep thyroid (6), whole lobes of rat thyroid (7), and homogenates of rat salivary gland (8). This relative inhibition of thyroid hormone formation induced by high concentrations of iodide is often termed the Wolff-Chaikoff phenomenon, and has never been fully explained. In normal animals, such inhibition is transient (9). Rarely, however, prolonged treatment with iodine does cause goiter and myxedema in man (10), possibly because the inhibitory effect of iodide persists.

Recently, evidence has accumulated that the formation of hormone and oxidative metabolism in the thyroid are closely linked. First, the iodideconcentrating mechanism is dependent on phosphate bond energy $(11,12)$, and second, organic binding of thyroidal iodide appears to depend on electron transfers leading to generation of hydrogen peroxide (13-16). The present studies were designed to determine whether

* This investigation was supported in part by U. S. Public Health Service research grants AM-00267-10 and AM-06650-01 from the National Institute of Arthritis and Metabolic Diseases, Bethesda, Md.

$\dagger$ A portion of this investigation was carried out during the tenure of a U. S. Public Health Service postdoctoral fellowship from the National Institute of Arthritis and Metabolic Diseases.

$\ddagger$ Investigator, Howard Hughes Medical Institute. changes in the rate of hormone formation induced by varying the availability of iodide to thyroid slices in vitro are associated with, or can be ascribed to, alterations of intermediary metabolism within the thyroid. A preliminary report of these studies has appeared (17).

\section{METHODS}

Preparation of slices. Thyroid glands were obtained from freshly killed sheep and were brought from the abattoir to the laboratory packed in ice. A single gland was used in each experiment. Slices were cut with a Stadie-Riggs microtome, washed twice in ice-cold physiological saline solution, weighed on a torsion balance, and placed in Warburg vessels containing 2 or $3 \mathrm{ml}$ of icecold medium. Tissue weights were quite uniform within individual experiments, but varied between approximately 50 and $300 \mathrm{mg}$ per flask in different experiments.

Preparation of media. The standard medium employed in control vessels was Krebs-Ringer-phosphate

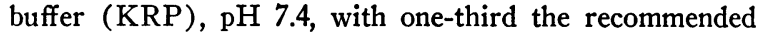
concentration of $\mathrm{CaCl}_{2}{ }^{1}$ (18). Each milliliter of medium contained 1.5 or $2.0 \mathrm{mg}$ of stable glucose, labeled with 0.5 to $1.5 \mu \mathrm{c}$ of $\mathrm{C}^{14} .2$ Vessels were incubated at $38^{\circ} \mathrm{C}$ under $100 \%$ oxygen in a Warburg apparatus for from 60 to 200 minutes. $\mathrm{CO}_{2}$ was absorbed by $0.2 \mathrm{ml}$ of $10 \%$ $\mathrm{KOH}$ in a sidearm.

Media containing desired concentrations of iodide were prepared by isosmotic substitution of $\mathrm{NaI}$ for $\mathrm{NaCl}$ in KRP. Several factors, however, might cause the ultimate concentration of iodide in the medium to deviate from that produced by the addition of $\mathrm{NaI}$. First, as judged by iodine analyses performed in 14 different preparations, ${ }^{3}$ the concentration of iodide in control media, representing contamination of the reagents

1 Modified Krebs-Ringer-phosphate buffer: $\mathrm{NaCl}, 0.132$ $\mathrm{M}$; $\mathrm{KCl}, 0.005 \mathrm{M}$; $\mathrm{CaCl}_{2}, 0.0009 \mathrm{M} ; \mathrm{MgSO}_{4}, 0.0013 \mathrm{M}$; and phosphate buffer, $0.009 \mathrm{M}$.

$2 \mathrm{C}^{14}$-labeled glucose was obtained from the New England Nuclear Corporation, Boston, Mass.

3 Performed at Boston Medical Laboratory, Boston. Mass. 
used, was considered negligible (average, $5.2 \mu \mathrm{g}$ per $100 \mathrm{ml}$, or $\left.4 \times 10^{-7} \mathrm{M}\right)$. Second, the quantity of iodide that might be leached from thyroid tissue during the incubation period was considered. Speciments of 9 separate thyroid glands were boiled in a test tube containing a small volume of distilled water. The entire contents of the tube were then placed in a dialysis sac and dialyzed overnight against distilled water at $4^{\circ} \mathrm{C}$. The calculated content of dialyzable iodine in thyroids, based upon iodine analyses in the dialyzing solution, averaged $2.1 \mu \mathrm{g}$ per $100 \mathrm{mg}$ of tissue. In view of the subsequent demonstration that thyroid tissue contains substantial quantities of iodinated peptides that are slowly dialyzable (19-21), this value was undoubtedly an overestimation of the true concentration of inorganic iodide in these specimens. Even if this were not the case, flasks containing $100 \mathrm{mg}$ of tissue and added iodide in a concentration of $1 \times 10^{-5} \mathrm{M}(1.27 \mu \mathrm{g}$ per $\mathrm{ml})$ would contain at least twice as much iodide as flasks containing tissue without added iodide. Furthermore, the glandular contribution of iodide would be insignificant in flasks in which media had been enriched to a concentration of $1 \times 10^{-4} \mathrm{M}$ or more. A third consideration was the ability of thyroid slices to perform iodinations and thereby to decrease the concentration of iodide in the medium. Here, too, this effect would almost always be negligible at iodide concentrations greater than $1 \times 10^{-4} \mathrm{M}$, where percentile organic binding of iodide seldom exceeds $0.5 \%(6,22) .4$ Finally, it is likely that any metabolic effects of iodide would be more closely related to concentration in the slice than to that in the medium, and that the activity of the iodide-concentrating mechanism would therefore influence the results obtained. Since slice/medium $(\mathrm{S} / \mathrm{M})$ iodide concentration gradients greater than one may exist at concentrations of iodide in the medium ranging up to $1 \times 10^{-3} \mathrm{M}(11)$, this factor was operative in most of the present studies. In them, no systematic attempt was made to correct for these factors. The iodide concentrations hereafter referred to therefore represent merely the concentration of iodide added to the medium, and flasks with no iodide will be termed "controls."

Measurements. Oxygen consumption was measured by standard manometric methods (18). $\mathrm{C}^{14} \mathrm{O}_{2}$ derived from labeled glucose was measured by methods previously described (15). In brief, these consisted of redistilling $\mathrm{CO}_{2}$ from $\mathrm{KOH}$ into $0.5 \mathrm{M}$ Hyamine, which was then transferred to vials containing liquid scintillator. Counting was carried out in a liquid scintillation counter, and counts in $\mathrm{C}^{14} \mathrm{O}_{2}$ were compared with counts in a sample of the initial medium, after correction for quenching. The recovery of counts from labeled glucose in vessels

4 That this effect might also be unimportant at lower concentrations of iodide is suggested by the work of Kondo (23). He found that, during active uptake of $\mathrm{I}^{131}$ by pig thyroid slices, iodide concentration in the medium remained constant or increased. Release of stable iodide from human and canine thyroid slices has been shown by Molnar, Albert, Keating, and Orvis (24). incubated without tissue was not determined in the majority of experiments. $\mathrm{C}^{\mathbf{1 4}}$-labeled lactate in suspending media was estimated by ascending paper chromatography in butanol : acetic acid: water $(100: 12: 88)$. That portion of the filter paper containing lactate was located by radioautography, excised, and placed in a vial of liquid scintillator for counting. Radioactivity in the lactate zone was compared with that in a sample of the initial medium applied to filter paper and counted under similar geometric conditions. Values for lactate production reported are the means of duplicate vessels; in no case did the value for an individual vessel differ from the reported mean by more than $7 \%$. Concentrations of stable glucose were measured in duplicate by the Somogyi-Nelson method (25) ; control studies indicated that iodide concentrations in the medium as high as $1 \times$ $10^{-1} \mathrm{M}$ did not influence the glucose measurement. Total $\mathrm{CO}_{2}$ production was determined by $\mathrm{BaCO}_{3}$ precipitation, with care taken to prevent contamination with atmospheric $\mathrm{CO}_{2}$.

Statistical treatment. With but few exceptions, all results presented are the average of closely agreeing values obtained in duplicate or triplicate vessels. With some of the results, analysis of variance and tests of significance were performed as described by Snedecor (26). For comparison of results obtained in many thyroid glands, however, of markedly different metabolic activity, from animals whose age and history of iodide ingestion were unknown, it seemed preferable to use nonparametric methods, which do not assume a normal distribution of results. Therefore, the "sign test" was also employed $(27,28)$. The null hypothesis tested was that the number of experiments showing an increase in a given function (e.g., $\mathrm{QO}_{2}$ ) at a given concentration of iodide would equal the number showing a decrease. The probability that the observed number of positive and negative differences occurred by chance was then taken from a standard table (28).

\section{RESULTS}

Oxygen consumption. In 41 experiments, oxygen consumption in control vessels averaged $28.6 \pm 8.7 \mu \mathrm{l}$ per hour per $100 \mathrm{mg}$ (mean $\pm \mathrm{SD}$ ). The changes in $\mathrm{QO}_{2}$ induced by varying concentrations of iodide in the medium are depicted in Figure 1, and their statistical significance is summarized in Table I. Low concentrations of iodide in the incubation medium $\left(5 \times 10^{-6}\right.$ to $1 \times 10^{-5}$ M) did not affect $\mathrm{QO}_{2}$ with significant consistency. At iodide concentrations between $5 \times 10^{-5}$ and $5 \times 10^{-4} \mathrm{M}$, however, there was almost invariably an increase of $\mathrm{QO}_{2}$ above control values (average, $+17 \%$ ), and this change was highly significant $(\mathrm{p}<0.001)$ by the sign test (Table I). Significant stimulation of $\mathrm{QO}_{2}$ above control values also occurred at iodide concentrations of 


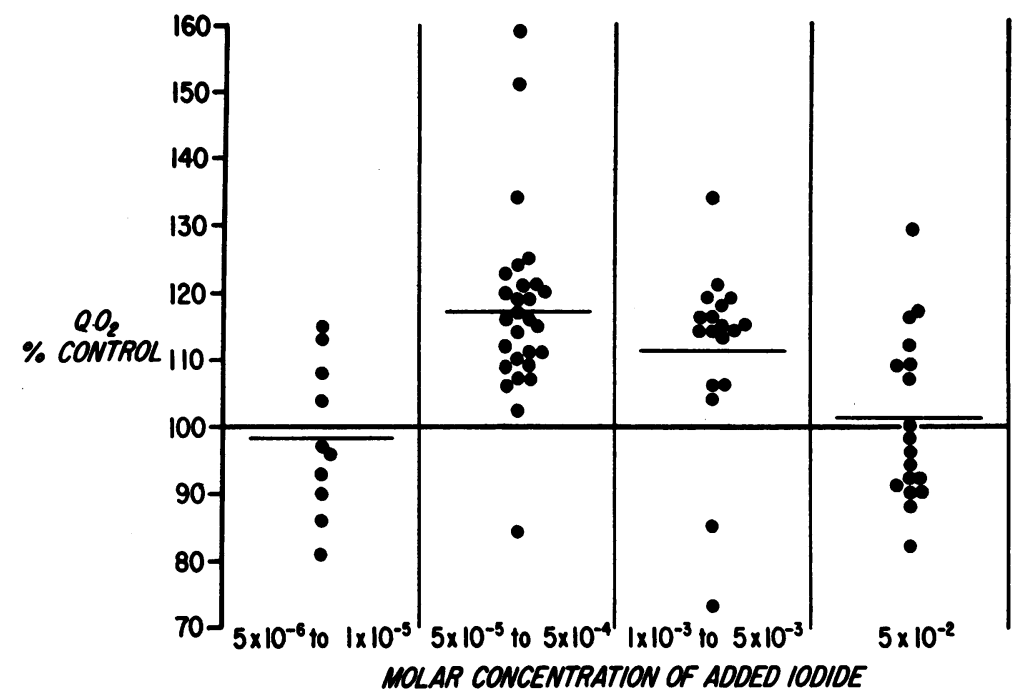

Fig. 1. EFFECTS OF INORGANIC IODIDE ON OXYGEN CONSUMPTION IN SHEEP THYROID SLICES. Within each concentration range, each point represents closely agreeing duplicate, triplicate, or quadruplicate results from a single thyroid gland.

$1 \times 10^{-3}$ to $5 \times 10^{-3} \mathrm{M}(\mathrm{p}<0.001)$, but was of smaller magnitude (average, $+11 \%)$ and, when directly compared, was usually less than the stimulation occurring at $5 \times 10^{-5}$ to $5 \times 10^{-4} \mathrm{M}$. At the higher iodide concentration of $5 \times 10^{-2} \mathrm{M}$, $\mathrm{QO}_{2}$ 's did not differ consistently from control values, but were consistently less than $\mathrm{QO}_{2}$ 's at the lower, stimulatory concentration ranges of iodide $\left(5 \times 10^{-5}\right.$ to $5 \times 10^{-4} \mathrm{M}$ and $1 \times 10^{-3}$ to $5 \times 10^{-3}$ $\mathrm{M})$.

In prolonged experiments, the rate of oxygen consumption declined slightly. In nine experiments 2 hours long or longer, $\mathrm{QO}_{2}$ 's during the second hour averaged $7 \%$ less than during the first hour. In six experiments lasting 3 hours, $\mathrm{QO}_{2}$ 's during the third hour averaged $9 \%$ less than during the second hour. The proportionate decline in $\mathrm{QO}_{2}$ with time was uninfluenced by the addition of iodide.

Experiments with uniformly-labeled glucose. In eight experiments, tissue was incubated in a standard concentration of stable glucose $(2 \mathrm{mg}$ per $\mathrm{ml}$ ) labeled with glucose-U-C ${ }^{14}$, and two standard concentrations of iodide $\left(1 \times 10^{-4} \mathrm{M}\right.$ and $\left.5 \times 10^{-2} \mathrm{M}\right)$. Tissue weights in these experiments averaged $196 \mathrm{mg}$, and incubations were

TABLE I

Effect of added iodide on oxygen consumption by sheep thyroid slices seen in comparisons by the "sign test"

\begin{tabular}{|c|c|c|c|c|}
\hline \multicolumn{2}{|c|}{ Iodide concentrations compared } & \multirow[b]{2}{*}{$\mathrm{n}^{*}$} & \multirow[b]{2}{*}{$x+$} & \multirow[b]{2}{*}{$\mathrm{p} \ddagger$} \\
\hline A & B & & & \\
\hline 0 & $5 \times 10^{-6}$ to $1 \times 10^{-5}$ & 10 & 4 & $>0.2$ \\
\hline 0 & $5 \times 10^{-5}$ to $5 \times 10^{-4}$ & 28 & 26 & $<0.001$ \\
\hline 0 & $1 \times 10^{-3}$ to $5 \times 10^{-3}$ & 18 & 16 & $<0.001$ \\
\hline 0 & $5 \times 10^{-2}$ & 18 & 8 & $>0.2$ \\
\hline $5 \times 10^{-6}$ to $1 \times 10^{-5}$ & $5 \times 10^{-5}$ to $5 \times 10^{-4}$ & 9 & 9 & 0.002 \\
\hline $1 \times 10^{-3}$ to $5 \times 10^{-3}$ & $5 \times 10^{-5}$ to $5 \times 10^{-4}$ & 17 & 12 & 0.072 \\
\hline $5 \times 10^{-2}$ & $5 \times 10^{-5}$ to $5 \times 10^{-4}$ & 15 & 15 & $<0.001$ \\
\hline $5 \times 10^{-2}$ & $1 \times 10^{-3}$ to $5 \times 10^{-3}$ & 10 & 9 & 0.011 \\
\hline
\end{tabular}
iodide.

${ }^{*} \mathrm{n}=$ number of experiments in which comparisons of $\mathrm{QO}_{2}$ 's were made at the indicated concentrations of added

$\dagger \mathrm{x}=$ number of experiments in which $\mathrm{QO}_{2}$ was greater at iodide concentration $\mathrm{B}$ than at iodide concentration $\mathrm{A}$. $\ddagger p=$ probability of difference between observed value of $x$ and $x=n / 2$. 
TABLE II

Effect of inorganic iodide on $C^{14} \mathrm{O}_{2}$ production from glucose-1-C $C^{14}$ and $-6-C^{14}$ in sheep thyroid slices*

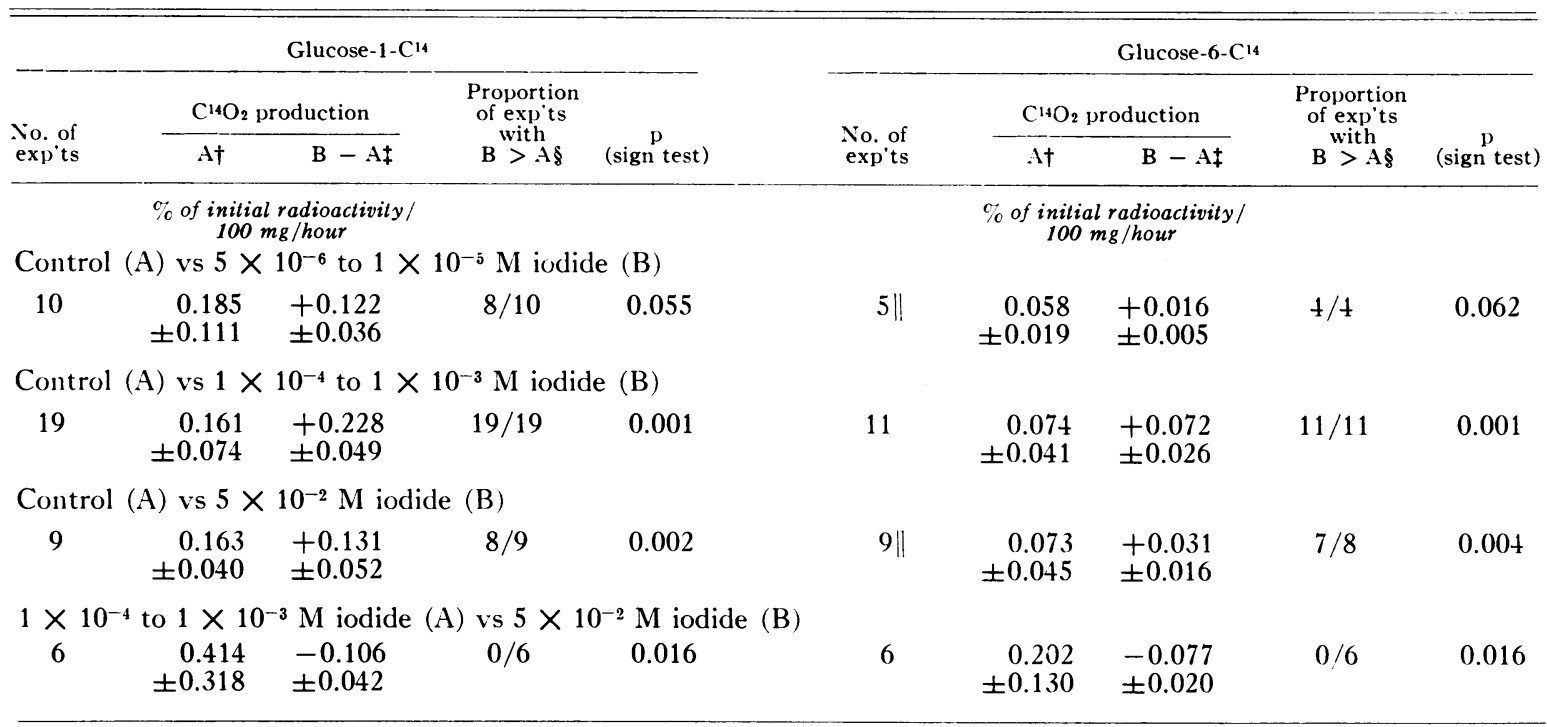

* Standard conditions for these experiments were $3 \mathrm{mg}$ glucose in $2 \mathrm{ml}$ medium in each flask, and incubation time of 60 minutes.

$+\mathrm{C}^{14} \mathrm{O}_{2}$ production at iodide concentration $\mathrm{A}$ (mean $\pm \mathrm{SD}$ ).

$\mp$ Difference between $\mathrm{C}^{14} \mathrm{O}_{2}$ production at iodide concentration $\mathrm{B}$ and that at concentration $\mathrm{A}$ (mean difference $\pm \mathrm{SE}$ of mean difference).

$\S$ Figures represent no. of experiments where $\mathrm{C}^{14} \mathrm{O}_{2}$ production at concentration $\mathrm{B}$ exceeded that at concentration $\mathrm{A} /$ no. of experiments where $B \neq A$. In the sign test, experiments where $B=A$ are not included $(27,28)$.

II In one experiment in this group, $\mathrm{B}=\mathrm{A}$.

allowed to proceed for an average of 165 minutes. Results obtained in this group of experiments are summarized in Table II; to facilitate comparisons among the various functions measured, data are expressed in micromoles.

In each of these eight experiments, changes in oxygen consumption were as noted above: stimulation at $10^{-4} \mathrm{M}$ iodide and loss of stimulation at $5 \times 10^{-2} \mathrm{M}$ iodide. Changes in the generation of $\mathrm{C}^{14} \mathrm{O}_{2}$ roughly paralleled those in oxygen consumption. ${ }^{5}$ At $1 \times 10^{-4} \mathrm{M}$ iodide, however,

${ }^{5}$ Hoskin has demonstrated that preparations of $\mathrm{C}^{14}$ labeled glucose contain volatile radioactivity that is collected into alkali, even in the absence of tissue (29). Tissue-free blanks were measured in three of these experiments, and blank radioactivity was less than $0.008 \%$ of initially added radioactivity. In 24 subsequent experiments with glucose- $U-\mathrm{C}^{14}$ from the same source, not reported here, the amount of radioactivity recovered in $\mathrm{KOH}$ in vessels free of tissue (thermobarometers) averaged $0.009 \pm 0.002 \%$ of medium radioactivity, and was uninfluenced by the addition of iodide. In the eight experiments reported here, radioactivity collected in alkali in vessels containing tissue and no added iodide averaged $0.46 \%$ of medium radioactivity (range, 0.21 to 0.88 ). Thus, it is unlikely that the true values for $\mathrm{C}^{14} \mathrm{O}_{z}$ there was in each experiment a greater percentile stimulation of $\mathrm{C}^{14} \mathrm{O}_{2}$ production than of $\mathrm{QO}_{2}$ (mean increase, 71 against 19\%). At $5 \times 10^{-2}$ II iodide, some glands (experiments 37 and 67) displayed distinct stimulation of $\mathrm{C}^{14} \mathrm{O}_{2}$ production when compared with controls, while others showed essentially no change.

From a comparison of moles of oxygen consumed with the estimate of moles of glucose carbon converted to $\mathrm{CO}_{2}$, the proportion of oxygen consumption attributable to oxidation of exogenous glucose was calculated. This proportion was relatively small, averaging $12 \%$ in control flasks, $18 \%$ at $1 \times 10^{-4} \mathrm{M}$ iodide, and $14 \%$ at $5 \times 10^{-2}$ $M$ iodide. However, of the increase in oxygen consumption induced by $1 \times 10^{-4} \mathrm{M}$ iodide (mean increment, $0.25 \mu$ moles per hour per $100 \mathrm{mg}$ tissue), $48 \%$ could be ascribed to increased oxidation of exogenous glucose.

Assimilation of glucose (disappearance from the medium) was measured in six experiments.

production differed materially from those presented in Table II. 
No consistent change induced by iodide could be detected. Errors in this estimation are relatively large, however, and the data do not exclude the possibility that small changes did occur. ${ }^{6}$ From the data in Table II, the proportion of assimilated glucose converted to $\mathrm{CO}_{2}$ averaged $2.9 \%$ in control flasks, $5.9 \%$ in those containing $1 \times 10^{-4} \mathrm{M}$ iodide, and $3.7 \%$ in the presence of $5 \times 10^{-2} \mathrm{M}$ iodide.

Respiratory quotients were determined in four experiments. Control values averaged 1.0, and no consistent changes were seen at either standard concentration of added iodide. Data with regard to the effects of iodide on the production of $\mathrm{C}^{14}$-labeled lactate yielded no evidence that the production of lactate was stimulated, and in two experiments (no. 37 and 67), iodide appeared to cause a decline in lactate production greater than the error of the method.

Analysis of variance of the data in Table II revealed that iodide produced significant changes only in oxygen consumption and in the production of $\mathrm{C}^{14} \mathrm{O}_{2}$. With the criteria suggested by Snedecor (26), values for both functions in flasks containing $1 \times 10^{-4} \mathrm{M}$ iodide were significantly higher than values in control flasks, or in those containing $5 \times 10^{-2} \mathrm{M}$ iodide. Differences between control flasks and those containing $5 \times$ $10^{-2} \mathrm{M}$ iodide were not significant.

Experiments with glucose-1-C $C^{14}$ and $-6-C^{14}$. Tissue-free blanks were not routinely incubated in experiments with either glucose-1-C $\mathrm{C}^{14}$ or $-6-\mathrm{C}^{14}$; in two experiments, a blank with glucose-6- $\mathrm{C}^{14}$ was incubated, and $0.01 \%$ of medium radioactivity was found in $\mathrm{KOH}$. In these studies with specifically labeled glucose, smaller amounts of tissue and shorter incubation times were employed than was the case in experiments with glucose-U-C ${ }^{14}$. Therefore, failure to correct for nonmetabolically generated radioactivity may have

\footnotetext{
${ }^{6}$ The actual changes in medium glucose concentration during incubation in these experiments averaged about $25 \mathrm{mg}$ per $100 \mathrm{ml}$, a difference easily measurable by the method used. As noted above, however, the mean increment in oxygen consumption induced by $1 \times 10^{-4} \mathrm{M}$ iodide was $0.25 \mu$ moles per hour per $100 \mathrm{mg}$ tissue. If this increment had been expended solely in the formation of $\mathrm{CO}_{2}$ from an increase in assimilated glucose, the difference in final glucose concentration between control flasks and those at $1 \times 10^{-4} \mathrm{M}$ would have been only about $2.5 \mathrm{mg}$ per $100 \mathrm{ml}$.
}

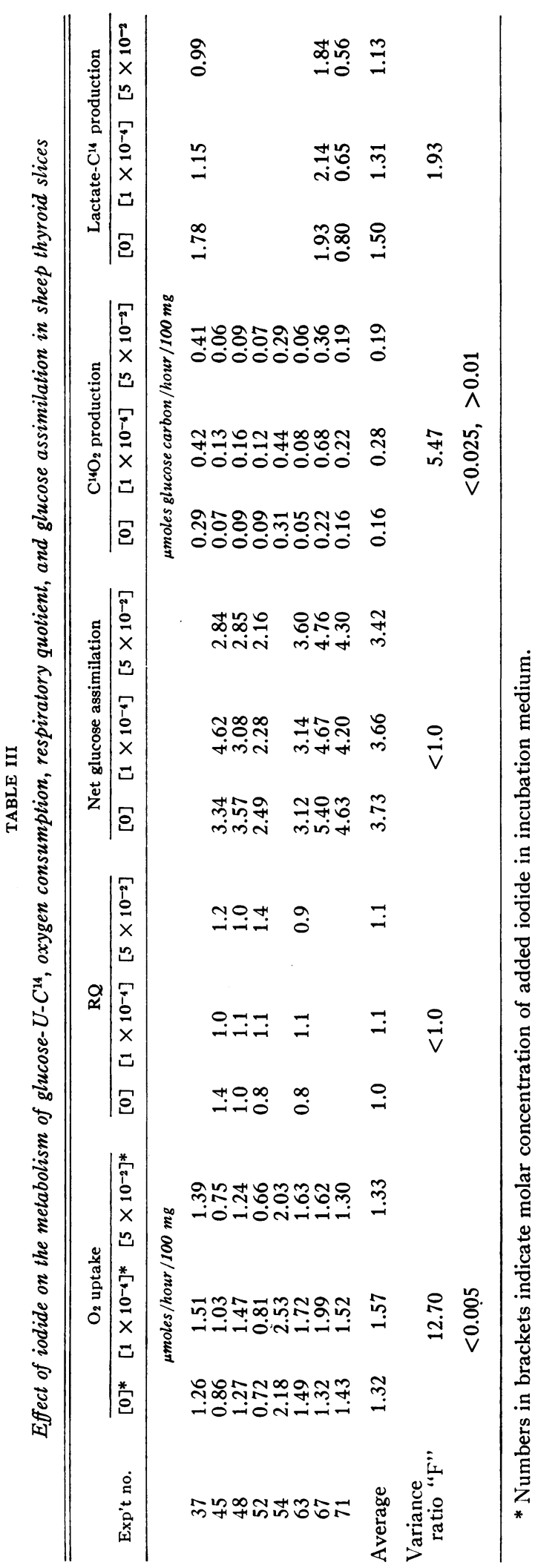




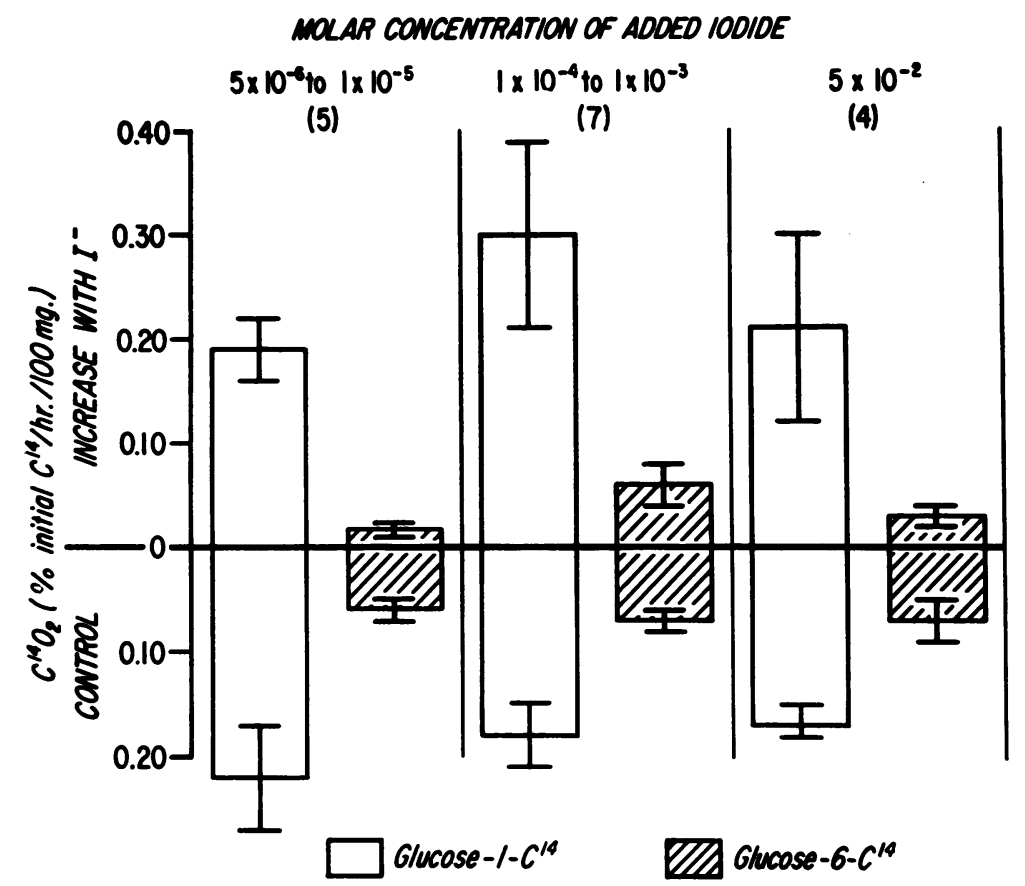

Fig. 2. Comparative effects of IODide on $\mathrm{C}^{14} \mathrm{O}_{2}$ PRODUCtion From GLU$\operatorname{cose}-1-\mathrm{C}^{14}$ AND $-6-\mathrm{C}^{14}$. Only experiments in which glucose-1-C $\mathrm{C}^{14}$ and $-6-\mathrm{C}^{14}$ were used concurrently are depicted. In each experiment, each flask contained $3 \mathrm{mg}$ glucose in $2 \mathrm{ml}$ medium. $\mathrm{C}^{14} \mathrm{O}_{2}$ production in control flasks is indicated downward from the zero line (mean $\pm \mathrm{SE}$ ); increases induced by the given concentrations of iodide are indicated upward from the zero line (mean difference $\pm \mathrm{SE}$ ) ; number of experiments is in parentheses. Open columns represent results with glucose- $1-\mathrm{C}^{14}$; hatched columns represent results with glucose-6- $\mathrm{C}^{14}$.

introduced significant errors in the determination of $\mathrm{C}^{14} \mathrm{O}_{2}$ production. Blank values may be assumed to be constant, however, among all the flasks in a single experiment; therefore, the amount of change in the generation of $\mathrm{C}^{14} \mathrm{O}_{2}$ induced by iodide in the medium can be accurately determined.

Results obtained in experiments with glucose$1-\mathrm{C}^{14}$ and $-6-\mathrm{C}^{14}$ are shown in Table III. At the lowest range of iodide concentrations employed $\left(5 \times 10^{-6}\right.$ to $\left.1 \times 10^{-5} \mathrm{M}\right)$, generation of $\mathrm{C}^{14} \mathrm{O}_{2}$ from C-1- and C-6-labeled glucose was increased, and the changes were of borderline statistical significance by the sign test. At intermediate concentrations of iodide $\left(1 \times 10^{-4}\right.$ to $\left.1 \times 10^{-3} \mathrm{M}\right)$, and at the highest concentration of iodide employed $\left(5 \times 10^{-2} \mathrm{M}\right)$, generation of $\mathrm{C}^{14} \mathrm{O}_{2}$ from both $\mathrm{C}-1$ - and C-6-labeled glucose was significantly increased. In experiments in which they were directly compared, effects of the intermediate concentrations of iodide were greater than those of the highest concentration.?

In a number of instances, the effects of iodide on the generation of $\mathrm{C}^{14} \mathrm{O}_{2}$ from $\mathrm{C}-1$ - and $\mathrm{C}-6$ labeled glucose were compared in the same experiment. Results obtained in these experiments are shown in Figure 2. In all cases, the increase in formation of $\mathrm{C}^{14} \mathrm{O}_{2}$ from glucose-1- $\mathrm{C}^{14}$ was far greater than from glucose-6-C $\mathrm{C}^{\mathbf{1 4}}$.

Effect of thionamide derivatives. The effects of thiouracil and methimazole in concentrations known to inhibit organic iodinations (11) were assessed in four experiments (Figure 3 ). In vessels free of added iodide, these agents slightly,

\footnotetext{
${ }^{7}$ It is not immediately apparent why $\mathrm{C}^{14} \mathrm{O}_{2}$ production was not consistently stimulated at an iodide concentration of $5 \times 10^{-2} \mathrm{M}$ in experiments using glucose- $U-C^{14}$, although such stimulation occurred rather consistently in experiments with glucose-1-C $\mathrm{C}^{14}$ and $-6-C^{14}$. Variation between the individual thyroid glands studied may be the best explanation.
} 
but consistently, inhibited the generation of $\mathrm{C}^{14} \mathrm{O}_{2}$ from glucose-1-C ${ }^{14}$, but had no appreciable effect on $\mathrm{QO}_{2}$. Both thiouracil and methimazole, however, completely or almost completely inhibited the stimulatory response of these functions to added iodide, and a methimazole concentration of $5 \times 10^{-3} \mathrm{M}$ did not appear to be more effective than one of $1 \times 10^{-4} \mathrm{M}$.

It may be presumed that both the stimulation of metabolism observed at moderate concentrations of iodide and the loss of stimulation at higher concentrations of iodide were more closely related to the concentration of iodide in the thyroid than to its concentration in the medium. In this regard, it has been clearly established that agents, such as methimazole, that inhibit organic binding in vivo concomitantly increase the concentration of iodide in the thyroid relative to that in the
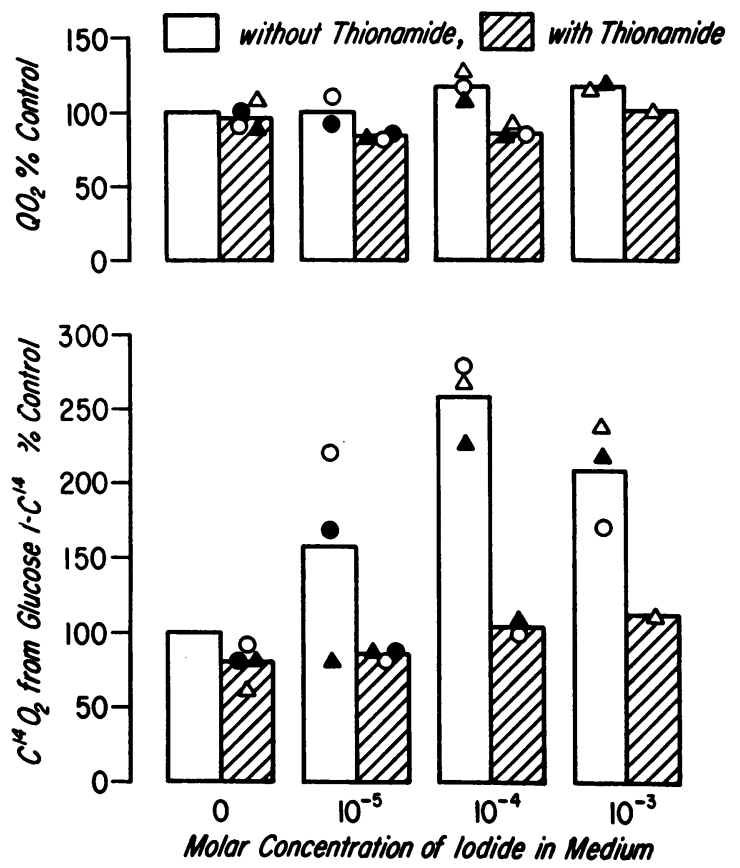

Fig. 3. The efFect of antithyroidal AGENTS ON IODIDE-INDUCED STIMULATION OF OXYGEN CONSUMPTION AND $\mathrm{C}^{14} \mathrm{O}_{2}$ PRODUCTION FROM GLUCOSE-1-C $\mathrm{C}^{14}$ IN SHEEP THYROID SLICES. Hatched columns represent flasks containing the antithyroidal agent. Each symbol represents results obtained with duplicate flasks in a single experiment. The agents used, and their concentrations, were: in experiment no. 14 (๑), $2 \times 10^{-3} \mathrm{M}$ thiouracil; in no. $32(\triangle), 5 \times 10^{-3} \mathrm{M}$ methimazole; in no. $34(\mathrm{O})$, $1 \times 10^{-3} \mathrm{M}$ methimazole; and in no. $35(\mathbf{\Delta}), 1 \times 10^{-4} \mathrm{M}$ methimazole.
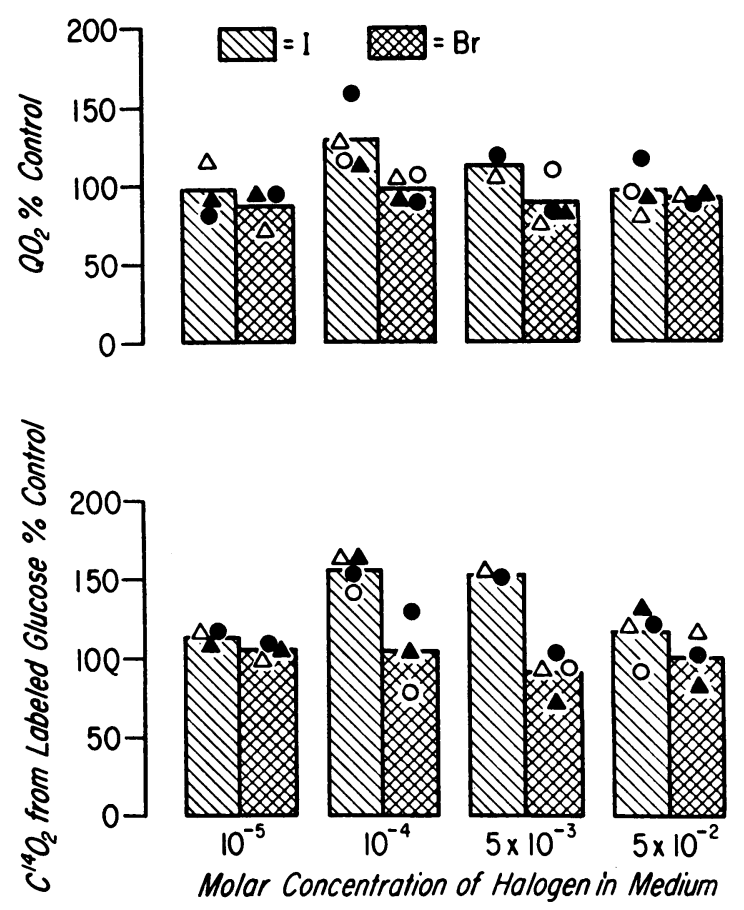

Fig. 4. THE EFFECT OF BROMIDE ON OXYGEN CONSLMPTION AND GLUCOSE OXIDATION IN SHEEP THYROID SLICES. Each symbol represents results obtained with duplicate flasks in a single experiment. In experiments $46(\triangle)$, $54(\mathrm{O})$, and $56(\bullet)$, glucose- $\mathrm{U}-\mathrm{C}^{14}$ was used ; in experiment $59(\mathbf{\Delta})$, glucose-1-C $\mathrm{C}^{14}$ was used. Diagonally hatched columns represent flasks supplemented with iodide; crosshatched columns represent flasks supplemented with bromide.

serum $(30,31){ }^{8}$ Thus, methimazole might have abolished the stimulatory effect of iodide by increasing the intrathyroidal concentration of iodide beyond the stimulatory range. The results of experiment 34 , however, suggested that this was not the case. Here, in the absence of methimazole, stimulatory effects of iodide were evident at concentrations ranging between $1 \times 10^{-5} \mathrm{M}$ and $1 \times 10^{-3} \mathrm{M}$ (Figure 3 ). In the presence of methimazole, no stimulation of metabolism was evident at an iodide concentration of $1 \times 10^{-5} \mathrm{M}$,

8 To test whether the same phenomenon occurs in vitro, slices were incubated in media containing $1 \times 10^{-5} \mathrm{M}$ iodide, with and without $1 \times 10^{-4} \mathrm{M}$ methimazole, and with tracer amounts of $\mathrm{I}^{131}$. After an hour of incubation, $\mathrm{I}^{131}$ in slice and medium was partitioned into organic and inorganic moieties by precipitation with trichloroacetic acid. Without methimazole, $58 \%$ of the $\mathrm{I}^{131}$ was organically bound, and the S/M iodide gradient was 20 . With methimazole, less than $1 \%$ of $\mathrm{I}^{131}$ was organically bound, and the $\mathrm{S} / \mathrm{M}$ iodide gradient was 46 . 
TABLE IV

Effect of iodide on the metabolism of sheep liver and kidney slices

\begin{tabular}{|c|c|c|c|c|c|c|c|c|}
\hline \multirow[b]{2}{*}{ Exp't no. } & \multirow[b]{2}{*}{ Tissue } & \multicolumn{3}{|c|}{$\mathrm{QO}_{2}$} & \multicolumn{4}{|c|}{$\mathrm{C}^{14} \mathrm{O}_{2}$ production from glucose- $\mathrm{C}^{14}$} \\
\hline & & Control & $10^{-4} \mathrm{M} \mathrm{I}^{-*}$ & $5 \times \mathrm{M} \mathrm{I}^{\times 10^{-2}}$ & $\begin{array}{l}\text { Labeled } \\
\text { carbon }\end{array}$ & Control & $10^{-4} \mathrm{M} \mathrm{I}^{-}$ & $5 \times \mathrm{M} \mathrm{I}^{-}$ \\
\hline & & $\begin{array}{l}\mu l / h o u r / \\
100 \mathrm{mg}\end{array}$ & $C_{C}$ control & $\%$ control & & $\begin{array}{c}\% C^{14} / \mathrm{hour} / \\
100 \mathrm{mg}\end{array}$ & $\%$ control & $C_{c}$ control \\
\hline $12 \mathrm{a}$ & Kidney & 133 & & 93 & $\begin{array}{l}\text { C-1 } \\
\text { C-6 }\end{array}$ & $\begin{array}{l}1.0 \\
0.67\end{array}$ & & $\begin{array}{l}73 \\
84\end{array}$ \\
\hline $20 \mathrm{a}$ & Kidney & 102 & & 99 & $\begin{array}{l}\text { C-1 } \\
\text { C-6 }\end{array}$ & $\begin{array}{l}0.70 \\
0.70\end{array}$ & & $\begin{array}{l}94 \\
68\end{array}$ \\
\hline $73 \mathrm{a}$ & Kidney & 166 & 96 & 9.3 & $\mathrm{C}-\mathrm{L}$ & 0.42 & 90 & 83 \\
\hline $76 a$ & Kidney & 132 & 105 & & $\mathrm{C}-\mathrm{U}^{-}$ & 0.56 & 98 & \\
\hline $12 \mathrm{~b}$ & Liver & & & & $\begin{array}{l}C-1 \\
C-6\end{array}$ & $\begin{array}{l}0.058 \\
0.017\end{array}$ & & $\begin{array}{l}71 \\
88\end{array}$ \\
\hline $20 \mathrm{~b}$ & Liver & 12.3 & & 92 & $\begin{array}{l}\text { C-1 } \\
\text { C-6 }\end{array}$ & $\begin{array}{l}0.072 \\
0.022\end{array}$ & & $\begin{array}{l}96 \\
77\end{array}$ \\
\hline $73 \mathrm{~b}$ & Liver & 23.4 & 81 & 55 & $\mathrm{C}-\mathrm{U}$ & 0.030 & 103 & 93 \\
\hline 74 & Liver & 32.3 & 110 & 85 & $\mathrm{C}-\mathrm{U}$ & 0.013 & 96 & 91 \\
\hline 75 & Liver & 32.8 & 92 & 96 & $\mathrm{C}-\mathrm{U}$ & 0.100 & 88 & 114 \\
\hline $76 b$ & Liver & 23.8 & 96 & & $\mathrm{C}-\mathrm{U}$ & 0.026 & 108 & \\
\hline
\end{tabular}

* Concentration of iodide added to incubation medium.

and by direct measurement, $\mathrm{S} / \mathrm{M}$ gradients for $\mathrm{I}^{131}$ were 30 . Thus, methimazole, in vessels containing $1 \times 10^{-5} \mathrm{M}$ iodine, could not have increased intrathyroidal iodide to a concentration higher than that present in flasks containing $1 \times$ $10^{-3} \mathrm{M}$ iodide and no methimazole.

Effect of bromide. Four experiments were performed to test the effects of supplementing incubation media with bromide, rather than iodide (Figure 4). Since preparations of bromide may be contaminated with iodide, the iodide concentrations of media enriched with bromide were determined. These, however, did not differ significantly from those of simultaneously prepared $\mathrm{KRP}$ (KRP, $3.6 \mu \mathrm{g} \mathrm{I}$ per $100 \mathrm{ml}$; KRP and $5 \times$ $10^{-2} \mathrm{M}$ bromide, $4.0 \mu \mathrm{g}$ I per $100 \mathrm{ml}$ ). Bromide had no consistent effects either on $\mathrm{QO}_{2}$, or on the production of $\mathrm{C}^{14} \mathrm{O}_{2}$ from glucose- $\mathrm{U}-\mathrm{C}^{14}$ (3 experiments) or glucose-1- $\mathrm{C}^{14}$ ( 1 experiment), even at the intermediate concentrations at which iodide was distinctly stimulatory.

Experiments with sheep liver and kidney slices. The concentration of iodide, $1 \times 10^{-4} \mathrm{M}$, that most consistently stimulated oxidations in thyroid slices had no similar effect on slices of sheep liver and kidney (Table IV). At the higher concentration of $5 \times 10^{-2} \mathrm{M}$, however, iodide had a consistent inhibitory effect on $\mathrm{QO}_{2}$ and decreased the generation of $\mathrm{C}^{14} \mathrm{O}_{2}$ from glucose-1- $\mathrm{C}^{14},-6-\mathrm{C}^{14}$, and $-\mathrm{U}-\mathrm{C}^{14} .^{9}$ Tissue-free blanks were incubated in all the experiments with glucose-U-C ${ }^{14}$, and correction was made for blank radioactivity. Such blanks were not performed in the experiments with glucose-1-C $C^{14}$ and $-6-C^{14}$.

\section{DISCUSSION}

The data presented here are generally in accord with earlier observations concerning the rate of oxygen consumption and glucose oxidation by sheep thyroid slices. They confirm previous studies indicating that the oxidation of exogenous glucose accounts for a relatively minor proportion (in the present studies, approximately $12 \%$ ) of

${ }^{9}$ If the intracellular concentration of iodide is the determinant of its metabolic effects, direct comparisons between the effects of standard extracellular concentrations of iodide on the thyroid and on other tissues that do not concentrate iodide are not possible. In liver and kidney, iodide is not actively concentrated $(32,33)$. Therefore, intracellular iodide concentrations in liver or kidney are probably lower than in thyroid when tissue slices from these respective organs are placed in media enriched with iodide at $1 \times 10^{-4} \mathrm{M}$; at this concentration, thyroid slices maintain $\mathrm{S} / \mathrm{M}$ gradients greater than unity (11). At a concentration of $5 \times 10^{-2} \mathrm{M}$ iodide, however, thyroidal S/M gradients decline below unity (11), and intracellular iodide concentrations in thyroid, liver, and kidney are probably quite similar. 
total oxygen consumption (34). This is consonant with the observation that the $\mathrm{QO}_{2}$ of thyroid slices is well-maintained although no substrate is added to the medium (35-37). The endogenous substrate whose oxidation accounts for most of the oxygen consumed is, however, unknown. It has been reported that the concentration of glycogen in thyroid tissue is very low (38) and is insufficient to support observed rates of oxygen consumption (39). On the other hand, in agreement with the findings of Weiss (35), respiratory quotients in the present studies were near unity, suggesting that a major portion of the endogenous substrate is derived from carbohydrate. No data are presently available on the catabolism by thyroid slices of either endogenous lipid or the large stores of protein and protein-bound hexoses that the thyroid contains (40). The fate of the major proportion of assimilated glucose is unknown, since a very small proportion ( 3 to $6 \%$ ) is converted to $\mathrm{CO}_{2}$, and only about $40 \%$ is converted to lactate.

The major finding of this study is that pronounced effects on certain aspects of thyroidal intermediatry metabolism can be acutely induced by variations in extracellular iodide concentration. These effects are biphasic: oxygen consumption and conversion of exogenous glucose to $\mathrm{CO}_{2}$ are stimulated by concentrations of iodide ranging up to approximately $1 \times 10^{-4} \mathrm{M}$, a finding which has also been reported by Dumont (41), whereas at higher concentrations of iodide, these oxidative processes return toward normal.

Tentative conclusions can be drawn concerning the nature of the stimulatory metabolic effects of iodide observed in the present study. First, iodide caused increased oxygen consumption. In the absence of added iodide, oxidation of endogenous substrate in the thyroid appeared to account for much of the oxygen consumed. Although stimulatory concentrations of iodide increased the proportion of the oxygen consumed that was utilized for the metabolism of exogenous glucose, endogenous compounds of unknown nature remained the principal oxidative substrate, and their metabolism must have been increased. Furthermore, absence of significant change in respiratory quotients in association with increased $\mathrm{QO}_{2}$ suggests that iodide changed the amount, rather than the nature, of the substrates concerned.
Evidence can be adduced concerning the pathways over which stimulatory concentrations of iodide produced their second major effect, increased production of $\mathrm{CO}_{2}$ from exogenous glucose. It is clear that the quantity of exogenous glucose oxidized in the hexose monophosphate (HMP) shunt increased, in view of the greater increase that iodide induced in $\mathrm{C}-1$ than in C- 6 oxidation. It cannot be concluded, however, that iodide increased the proportion of glucose metabolized via the HMP shunt. ${ }^{10}$ Any factor that generally stimulates glucose metabolism will be manifested by a prompter increase in $\mathrm{C}-1$ than in $\mathrm{C}-6$ oxidation, since $\mathrm{C}-1$ is immediately available for oxidation by the shunt, whereas C- 6 must traverse a much longer series of reactions and be diluted in a greater number of intermediate pools before appearing as $\mathrm{CO}_{2}$. This is reflected in Dumont's finding that the ratio between $\mathrm{C}^{14} \mathrm{O}_{2}$ production from glucose-1- $\mathrm{C}^{14}$ and from glucose-6- $\mathrm{C}^{14}$ (the "C-1/C-6 ratio") declines progressively with time (44). This decline also occurs at stimulatory concentrations of iodide (22).

Several considerations indicate that the HMP shunt was not the sole metabolic pathway stimulated by iodide. These follow from the increase in the generation of $\mathrm{C}^{14} \mathrm{O}_{2}$ from glucose-6- $\mathrm{C}^{14}$ that iodide induced. This could have occurred merely as a result of increased formation of triose$\mathrm{C}^{14}$, without any alteration in its proportionate conversion to $\mathrm{CO}_{2}$. Had this been the case, then the percentile increase in formation of lactate$\mathrm{C}^{14}$ should have equalled the percentile increase in formation of $\mathrm{C}^{14} \mathrm{O}_{2}$ from glucose-6- $\mathrm{C}^{14}$. A change of this magnitude (an increase of over $50 \%$ at $1 \times 10^{-4} \mathrm{M}$ iodide) should readily have

${ }^{10} \mathrm{Katz}$ and Wood have recently described a method for calculating the proportion of glucose metabolized via the HMP shunt by use of the fractional yields of $\mathrm{C}^{14} \mathrm{O}_{2}$ from assimilated $\mathrm{C}-1$ - and $\mathrm{C}$-6-labeled glucose (42). Although yields of $\mathrm{C}^{14} \mathrm{O}_{2}$ from $\mathrm{C}-1$ - and $\mathrm{C}-6$-labeled glucose were not precisely determined in the present studies, owing to failure to correct values for volatile contaminants in the glucose, this method was used to provide a first-order approximation of the percentile contribution of the HMP shunt to exogenous glucose metabolism in sheep thyroid slices. Calculations revealed this to be no more than a few per cent in control slices. Such low values are consonant with recent observations that the yields of $\mathrm{C}^{14}$-labeled lactate from glucose- $\mathrm{U}-\mathrm{C}^{14}$ or $-1-C^{14}$ do not differ appreciably from the yields of labeled lactate obtained with glucose-6- $C^{14}(43)$. 
been detectable by the method employed for lactate measurement, and no such change occurred. Thus, the increased formation of $\mathrm{C}^{14} \mathrm{O}_{2}$ from glucose-6- $\mathrm{C}^{14}$ appears to have resulted from an increase in the proportionate conversion of triose to $\mathrm{CO}_{2}$. This increase could occur for several reasons. First, acetate- $\mathrm{C}^{14}$ derived from exogenous glucose may, in the presence of iodide, have been diluted to a lesser extent by acetate derived from unlabeled endogenous sources. This explanation seems inconsistent with the large increase in the oxidation of endogenous substrate that iodide induced. Second, a proportion of $\mathrm{C}^{14}$ reaching the 3 -carbon pool may have been diverted from various synthetic reactions (e.g., formation of lipids and amino acids) to the formation of $\mathrm{CO}_{2}$. The present data do not exclude this possibility. Finally, iodide may have directly stimulated oxidative disposition of Krebs-cycle intermediates. Such an increase in Krebs-cycle oxidations could have resulted from an uncoupling of oxidative phosphorylation, such as iodide induces in rat liver mitochondria (45). Alternatively, it might reflect an increase in the availability of cofactors, such as oxidized pyridine nucleotides and flavins. This explanation seems especially attractive in view of the evidence of increased activity of both the HMP shunt and the Krebs cycle, as discussed above.

Several findings indicate that the stimulatory effects of moderate concentrations of iodide on thyroidal metabolism, whatever the pathways mediating them, are related to the effects of iodide on the rate of hormone synthesis. First, like the presently demonstrated increases in $\mathrm{QO}_{2}$ and $\mathrm{C}^{14} \mathrm{O}_{2}$ production, total iodinations in sheep thyroid slices increase progressively as the iodide concentration in the medium is increased to approximately $1 \times 10^{-4} \mathrm{M}$ (6). Second, when organic iodinations are inhibited by methimazole or thiouracil, stimulation of metabolism by iodide is abolished. Furthermore, no metabolic stimulation is induced by bromide, a halogen that undergoes negligible organic binding (46-48). Finally, iodide induces no metabolic stimulation in liver and kidney, tissues that do not organically bind iodide. These findings suggest that the oxidation of iodide is linked to and somehow influences the rate of other thyroidal oxidations. The apparent paradox, that oxidation of one substrate, i.e., iodide, can increase the rate of oxidation of other substrates, can be explained in several ways.

First, studies in thyroid homogenates and subcellular fractions have demonstrated a peroxidase capable of oxidizing iodide in the presence of $\mathrm{H}_{2} \mathrm{O}_{2}(13,14)$. Evidence has recently been presented suggesting that the same enzyme may catalyze both the formation of $\mathrm{H}_{2} \mathrm{O}_{2}$ and subsequent peroxidations (49). The reactions involved in the generation of $\mathrm{H}_{2} \mathrm{O}_{2}$ probably occur according to the following sequence $(15,16)$ :

$$
\begin{aligned}
& \text { TPNH (or DPNH)+H+ } \mathrm{H}^{+}+\text {flavoprotein } \rightarrow \\
& \text { TPN }\left(\text { or } D P N^{+}\right)+\text {flavoprotein } \cdot \mathrm{H}_{2} \\
& \text { flavoprotein } \cdot \mathrm{H}_{2}+\mathrm{O}_{2} \rightarrow \mathrm{H}_{2} \mathrm{O}_{2}+\text { flavoprotein } \\
& \mathrm{H}_{2} \mathrm{O}_{2}+2 \mathrm{I}^{-}+2 \mathrm{H}^{+} \rightarrow 2 \mathrm{I}^{\circ}+2 \mathrm{H}_{2} \mathrm{O} . \\
& \text { Over-all: } \\
& \text { TPNH }
\end{aligned}
$$

If this is the correct mechanism, then it would follow from the present results that the rate of the over-all reaction depends on the concentration of iodide. In this way, oxidation of iodide could directly increase oxygen consumption and could indirectly stimulate other substrate oxidations by increasing the availability of oxidized pyridine nucleotides. Implicit in this argument, however, is the suggestion that the rate of peroxide formation is controlled by the rate of peroxide utilization, a situation not clearly shown to occur in biological systems. ${ }^{11}$

One argument against the foregoing mechanism derives from stoichiometric considerations. In the postulated sequence of reactions, one mole of oxygen should be consumed for every two moles of iodide oxidized. An iodide concentration of $1 \times 10^{-4} \mathrm{M}$ in the medium, however, increased oxygen consumption by as much as $1.5 \mu$ moles per flask, although the flask contained only $0.2 \mu$ mole of iodide, of which only a small proportion would be expected to have undergone organic binding (6). This objection can be overcome, however,

\footnotetext{
11 As an alternative to this mechanism, it may be that reactions 1 and 2 proceed at a constant rate and that only reaction 3 is stimulated by iodide. If this were the case, and if, when the supply of iodide was limited, $\mathrm{H}_{2} \mathrm{O}_{2}$ were attacked by catalase, iodide would still stimulate net oxygen consumption, since the catalatic process returns one mole of oxygen for each two moles of $\mathrm{H}_{2} \mathrm{O}_{2}$ degraded. This mechanism per se, however, would not provide for increased substrate oxidations.
} 
by postulation of a cyclic oxidation and reduction of iodine. This could come about in either of two ways. First, the thyroid appears to contain inhibitors of organic iodinations, such as ascorbic acid or glutathione (GSH) $(15,49,50)$, that could reduce oxidized iodine before it is organically bound. If the inhibitor were GSH, the reaction (no. 5) would be : $2 G S H+2 I^{\circ} \rightarrow G S S G$ $+2 \mathrm{H}^{+}+2 \mathrm{I}^{-}$. Since glutathione reductase is present in thyroid tissue $(15,51)$, the following reaction (no. 6) would also be expected: GSSG+ $\mathrm{TPNH}+\mathrm{H}^{+} \rightarrow 2 \mathrm{GSH}+\mathrm{TPN}^{+}$.

A second, less direct mechanism for the reduction of iodine involves the deiodination of iodotyrosines by the thyroidal iodotyrosine deiodinase (52). This enzyme is TPNH-dependent (53, 54 ), and its operation presumably results in the generation of TPN from TPNH. In view of the recent demonstration that the thyroid contains free iodotyrosines that are rapidly turning over (55), a substantial recycling of iodide through iodotyrosines may occur.

Both mechanisms cited above for the reduction to iodide of an oxidized form of iodine provide for the generation of TPN from TPNH, and both might therefore be expected to enhance glucose oxidation. Indeed, addition of iodotyrosines to thyroid tissue has been shown to have this effect $(38,41,56)$. If reactions 1 to 4 are also relevant, each mole of iodide cycled through an oxidation and reduction would consume $\frac{1}{2}$ mole of oxygen and would generate one mole of TPN. To the extent that extensive recycling of iodine occurs, therefore, especially when intrathyroidal iodide is moderately enhanced, a cascade of electron transfers would occur and would be associated with increases in both $\mathrm{QO}_{2}$ and substrate oxidations. Quantitatively, this would be poorly reflected in net organic iodinations.

Finally, a third mechanism by which iodide may stimulate substrate oxidations has been suggested by de Groot and Davis, who demonstrated that an enzyme solubilized from a sheep-thyroid particulate fraction can peroxidize reduced pyridine nucleotides (57). The activity of this enzyme, and hence the generation of oxidized pyridine nucleotides, is directly related to iodide concentration, since iodide apparently protects the enzyme from degradation.

Although the foregoing mechanisms may ac- count for the stimulatory effects of moderate concentrations of iodide on thyroidal oxidative metabolism, there remains to be considered the cause of the decline in or loss of stimulation occurring when concentrations of iodide are further increased. This biphasic metabolic response resembles the biphasic response of total organic iodinations to increasing concentrations of extracellular iodide, and thus provides a further suggestion that the oxidative metabolism of the thyroid gland and its rate of hormone formation are closely related. Both in vitro and in vivo, the thyroid responds to acute increases in extracellular iodide concentration with increasing organic iodinations. Beyond a critical concentration range, however, which in sheep slices is approximately $1 \times 10^{-4} \mathrm{M}(6)$, organic iodinations decline, although not necessarily to control levels. Two types of relationship between this so-called Wolff-Chaikoff effect and the biphasic effects of extracellular iodide on thyroidal oxidative metabolism can be envisioned. First, if the rate of iodide oxidation in some measure regulates oxidative intermediary metabolism in the thyroid, as suggested above, then declining oxidation of iodide during the Wolff-Chaikoff effect may explain the lessening of metabolic stimulation. It has been suggested that the Wolff-Chaikoff effect is due to complexing of oxidized iodine with iodide, in the presence of high concentrations of the latter, to form the triiodide ion $\mathrm{I}_{3}^{-}$, which is incapable of carrying out iodination (8). This theory, still unproven, does not predicate a decreased initial oxidation of iodide. It does imply, however, that the TPNH-oxidizing reactions secondary to the recycling of iodide, which appear to be critical to the production of an appreciable metabolic effect, would be diminished or abolished.

An alternate relationship between the WolffChaikoff effect and the decline in metabolic stimulation occurring at high concentrations of iodide also seems plausible. In vitro, high concentrations of iodide have been shown to inhibit two enzymes involved in oxidative metabolism: glucose6-phosphate dehydrogenase (58) and fumarase (59). Such inhibition could account for the decrease in $Q_{2}$ and $\mathrm{C}^{14} \mathrm{O}_{2}$ production that high concentrations of iodide induced in slices of liver and kidney. Other related enzymes, such as aldolase (60) and lactic dehydrogenase (61), are 
inhibited by molecular iodine, possibly through oxidation of sulfhydryl groups (62). If physiologically significant, such inhibition should be especially prone to occur in the thyroid. Thus, direct enzyme inhibition by iodide or iodine could explain both the declining phase of the intermediary metabolic response to varying concentrations of iodide and the secondary decline in the metabolically linked oxidation of iodide. At present, however, the data are insufficient to determine whether the effects of high concentrations of iodide are exerted primarily on iodide oxidation, or on intermediary metabolism, or whether, in fact, the two effects are interrelated.

\section{SUM MARY}

Enrichment of incubation media with increasing concentrations of inorganic iodide induced pronounced and biphasic alterations in the oxygen consumption and glucose metabolism of sheep thyroid slices. Moderate concentrations of iodide (up to $1 \times 10^{-4} \mathrm{M}$ ) enhanced both $\mathrm{QO}_{2}$ and the generation of $\mathrm{C}^{14} \mathrm{O}_{2}$ from glucose- $\mathrm{U}^{-\mathrm{C}^{14}},-1-\mathrm{C}^{14}$, and $-6-C^{14}$. At high concentrations of added iodide $\left(5 \times 10^{-2} \mathrm{M}\right)$, stimulation of these functions was diminished or absent.

The stimulatory effects of moderate concentrations of iodide appeared to be related to the oxidation or organic binding of increased quantities of iodine for the following reasons: 1) stimulatory effects were inhibited by methimazole and thiouracil, 2) bromide failed to stimulate thyroidal oxidations, and 3) no stimulation of oxidations was evident in slices of liver or kidney.

It is postulated that the stimulatory effects of iodide on glucose oxidation result from an enhanced oxidation of reduced coenzymes that may occur during both the oxidation of iodide and its subsequent reduction.

The loss of metabolic stimulation occurring at higher concentrations of iodide is of uncertain origin, but may be related, as either cause or effect, to the inhibition of thyroid hormone formation that high concentrations of thyroidal iodide acutely induce.

\section{ACK NOWLEDGMENTS}

The authors are indebted to Miss Ellen Cavanaugh, Miss Patricia Eveleth, and Mrs. Shu-hsien King for valuable technical assistance.

\section{REFERENCES}

1. Wolff, J., and I. L. Chaikoff. The inhibitory action of iodide upon organic binding of iodine by the normal thyroid gland. J. biol. Chem. 1948, 172, 855.

2. Wolff, J., and I. L. Chaikoff. Plasma inorganic iodide, a chemical regulator of normal thyroid function. Endocrinology 1948, 42, 468.

3. Nagataki, S., and S. H. Ingbar. The relation between qualitative and quantitative alteration in thyroid hormone synthesis induced by varying doses of iodide. Endocrinology. In press.

4. Stanley, M. M. The direct estimation of the rate of thyroid hormone formation in man. The effect of the iodide ion on thyroid iodine utilization. J. clin. Endocr. 1949, 9, 941.

5. Reinwein, D., and E. Klein. Der Einfluss des anorganischen Blutjodes auf den Jodumsatz der menschlichen Schilddrüse. Acta endocr. (Kbh.) 1960, 35, 485.

6. Morton, M. E., I. L. Chaikoff, and S. Rosenfeld. Inhibiting effect of inorganic iodide on the formation in vitro of thyroxine and diiodotyrosine by surviving thyroid tissue. J. biol. Chem. 1944, 154, 381.

7. Braverman, L. E., and S. H. Ingbar. Changes in thyroidal function during adaptation to large doses of iodide. J. clin. Invest. 1963, 42, 1216.

8. Serif, G. S., and S. Kirkwood. The mechanism of the antithyroid action of iodide ion. Endocrinology 1956, 58, 23.

9. Wolff, J., I. L. Chaikoff, R. C. Goldberg, and J. R. Meier. The temporary nature of the inhibitory action of excess iodide on organic iodine synthesis in the normal thyroid. Endocrinology 1949, 45, 504.

10. Paris, J., W. M. McConahey, C. A. Owen, Jr., L. B. Woolner, and R. C. Bahn. Iodide goiter. J. clin. Endocr. 1960, 20, 57.

11. Freinkel, N., and S. H. Ingbar. The relationship between metabolic activity and iodide-concentrating capacity of surviving thyroid slices. J. clin. Endocr. 1955, 15, 442.

12. Freinkel, N., and S. H. Ingbar. Effect of metabolic inhibitors upon iodide transport in sheep thyroid slices. J. clin. Endocr. 1955, 15, 598.

13. Serif, G. S., and S. Kirkwood. Enzyme systems concerned with the synthesis of monoiodotyrosine. II. Further properties of the soluble and mitochondrial systems. J. biol. Chem. 1958, 233, 109.

14. Alexander, N. M. Iodide peroxidase in rat thyroid and salivary glands and its inhibition by antithyroid compounds. J. biol. Chem. 1959, 234, 1530.

15. Schussler, G. C., and S. H. Ingbar. The role of intermediary carbohydrate metabolism in regulating organic iodinations in the thyroid gland. J. clin. Invest. 1961, 40, 1394. 
16. DeGroot, L. J., and A. M. Davis. Studies on the biosynthesis of iodotyrosine. J. biol. Chem. 1961, 236, 2009.

17. Green, W. L., and S. H. Ingbar. Effects of iodine on the intermediary metabolism of the thyroid gland and their relation to iodine-induced inhibition of thyroid hormone formation (abstract). J. clin. Invest. 1961, 40, 1045.

18. Umbreit, W. W., R. H. Burris, and J. F. Stauffer. Manometric Techniques, 3rd ed. Minneapolis, Burgess, 1957.

19. Lissitsky, S., J. Grégoire, J. Grégoire, and N. Limo$z$ in. The presence and in vitro activity of free iodinated peptides in the thyroid gland of mammals and man. Gen. comp. Endocr. 1961, 1, 519.

20. Halmi, N. S., and R. Pitt-Rivers. The iodide pools of the rat thyroid. Endocrinology 1962, 70, 660.

21. Nagataki, S., and S. H. Ingbar. Observations on the separation and measurement of inorganic iodine in rat thyroid glands. Endocrinology 1963, $72,480$.

22. Green, W. L., and S. H. Ingbar. Unpublished observations.

23. Kondo, $\mathrm{Y}$. Iodine metabolism in pig thyroid slices and effect of thyrotropic hormone. J. Biochem. (Tokyo) 1961, 50, 135.

24. Molnar, G. D., A. Albert, F. R. Keating, Jr., and A. L. Orvis. Iodine metabolism in surviving human and canine thyroid slices. Endocrinology 1956, 58, 381.

25. Nelson, N. A photometric adaptation of the Somogyi method for the determination of glucose. J. biol. Chem. 1944, 153, 375.

26. Snedecor, G. W. Statistical Methods, 5th ed. Ames, Iowa, Iowa State University Press, 1956.

27. Siegel, S. Nonparametric Statistics for the Behavioral Sciences. New York, McGraw-Hill, 1956.

28. Dixon, W. F., and F. J. Massey, Jr. Introduction to Statistical Analysis. New York, McGraw-Hill, 1951.

29. Hoskin, F. C. G. A source of error in the use of radioactive substrates for metabolic studies. Arch. Biochem. 1960, 87, 151.

30. Wollman, S. H., and R. O. Scow. Effect of propylthiouracil on the ratio of the radioiodide concentrations in thyroid gland and serum in normal and hypophysectomized rats. Endocrinology 1955, 56, 445.

31. Wollman, S. H., and R. O. Scow. Effect of various goitrogens and of dose of propylthiouracil on the ratio of radioiodide concentrations in the thyroid gland and serum in mice. Endocrinology 1955, $56,448$.

32. Halmi, N. S., R. G. Stuelke, and M. D. Schnell. Radioiodide in the thyroid and in other organs of rats treated with large doses of perchlorate. Endocrinology 1956, 58, 634.

33. Halmi, N. S., L. T. King, R. R. Widner, A. C. Hass, and R. G. Stuelke. Renal excretion of radioiodide in rats. Amer. J. Physiol. 1958, 193, 379.
34. Freinkel, N. Further observations concerning the action of pituitary thyrotropin on the intermediate metabolism of sheep thyroid tissue in vitro. Endocrinology 1960, 66, 851.

35. Weiss, B. Carbohydrate utilization by beef thyroid tissue. J. biol. Chem. 1951, 193, 509.

36. Freinkel, N., and S. H. Ingbar. Metabolic determinants of the iodide-concentrating capacity of surviving thyroid slices. Trans. Amer. Goiter Ass. 1954, 25.

37. Dumont, J. E. Pyruvate oxidation in thyroid tissue. Biochim. biophys. Acta (Amst.) 1962, 56, 382.

38. Field, J. B., I. Pastan, B. Herring, and P. Johnson. Studies on the mechanism of action of thyroid stimulating hormone on glucose oxidation. Biochim. biophys. Acta (Amst.) 1961, 50, 513.

39. Freinkel, N. The intermediary metabolism of thyroid tissue in The Thyroid Gland, R. Pitt-Rivers and W. R. Trotter, Eds. London, Butterworths, in press.

40. Boas, N. F., and J. B. Foley. Electrophoretic studies on the distribution of hexosamine in proteins of the thyroid gland. Endocrinology 1955, 56, 474.

41. Dumont, J. E. Effets in vitro de l'iodure et de la diiodotyrosine sur le shunt hexosemonophosphate thyroïdien. C. R. Soc. Biol. (Paris) 1961, 155, 2225.

42. Katz, J., and H. G. Wood. The use of $\mathrm{C}^{14} \mathrm{O}_{2}$ yields from glucose-1- and $-6-\mathrm{C}^{14}$ for the evaluation of the pathways of glucose metabolism. J. biol. Chem. 1963, 238, 517.

43. Barakat, R., W. L. Green, and S. H. Ingbar. Unpublished observations.

44. Dumont, J. E. Hexose monophosphate pathway in thyroid tissue. Biochim. biophys. Acta (Amst.) 1960, 40, 354.

45. Middlebrook, M., and A. Szent-Györgyi. The action of iodide on oxidative phosphorylation. Biochim. biophys. Acta (Amst.) 1955, 18, 407.

46. Perlman, I., M. E. Morton, and I. L. Chaikoff. The selective uptake of bromine by the thyroid gland with radioactive bromine as indicator. Amer. J. Physiol. 1941, 134, 107.

47. Yagi, Y., R. Michel, and J. Roche. Sur le métabolisme des bromures radioactifs $\left({ }^{82} \mathrm{Br}\right)$. Bull. Soc. Chim. biol. (Paris) 1953, 35, 289.

48. Alexander, N. M. The mechanism of iodination reactions in thyroid glands. Endocrinology 1961, $68,671$.

49. Klebanoff, S. J., C. Yip, and D. Kessler. The iodination of tyrosine by beef thyroid preparations. Biochim. biophys. Acta (Amst.) 1962, 58, 563.

50. Suzuki, M., M. Nagashima, and K. Yamamoto. Studies on the mechanism of iodination by the thyroid gland: iodide-activating enzyme and an intracellular inhibitor of iodination. Gen. comp. Endocr. 1961, 1, 103. 
51. Manso, C., and F. Wróblewski. Glutathione reductase activity in blood and body fluids. J. clin. Invest. 1958, 37, 214.

52. Roche, J., R. Michel, O. Michel, and S. Lissitzky. Sur la déshalogénation enzymatique des iodotyrosines par le corps thyroide et sur son rôle physiologique. Biochim. biophys. Acta (Amst.) 1952, 9, 161.

53. Stanbury, J. B. The requirement of monoiodotyrosine deiodinase for triphosphopyridine nucleotide. J. biol. Chem. 1957, 228, 801.

54. Stanbury, J. B., and M. L. Morris. Deiodination of diiodotyrosine by cell-free systems. J. biol. Chem. 1958, 233, 106.

55. Pitt-Rivers, R., and R. R. Cavalieri. The free iodotyrosines of the rat thyroid gland. Biochem. J. 1963, 86, 86.

56. Dumont, J. E. Stimulation in vitro of hexose monophosphate pathway in thyroid by iodotyrosines and synkavit. Biochim. biophys. Acta (Amst.) 1961, 50, 506.
57. De Groot, L. J., and A. M. Davis. Studies on the biosynthesis of iodotyrosines. Reduced pyridine nucleotide peroxidation by a thyroidal-iodinating enzyme. Biochim. biophys. Acta (Amst.) 1962, 59, 581.

58. Dickens, F., and H. McIlwain. Phenazine compounds as carriers in the hexosemonophosphate system. Biochem. J. 1938, 32, 1615.

59. Massey, V. Studies on fumarase. 2. The effects of inorganic anions on fumarase activity. Biochem. J. 1953, 53, 67.

60. Herbert, D., H. Gordon, V. Subrahmanyan, and D. E. Green. Zymohexase. Biochem. J. 1940, 34, 1108.

61. Neilands, J. B. Studies on lactic dehydrogenase of heart. III. Action of inhibitors. J. biol. Chem. 1954, 208, 225.

62. Olcott, H. S., and A. Fraenkel-Conrat. Specific group reagents for proteins. Chem. Rev. 1947, 41, 151. 